\title{
„BEZDROŻA KAPITALIZMU”: \\ LUDWIK LANDAU I JEGO STATYSTYCZNA \\ WIZJA GLOBALNYCH NIERÓWNOŚCI ${ }^{1}$
}

Małgorzata Mazurek

Columbia University

U progu drugiej wojny światowej Ludwik Landau (1902-1944) pisał o jednym z najważniejszych problemów lat 30.: „Zjawisko «ludzi zbędnych», równie charakterystyczne dla Chin, jak dla Polski, czy Hiszpanii, jest prawdziwą klęską dotykającą milionowe rzesze ludności obojga płci. Wszelkie wady w strukturze agrarnej kraju, w podziale ziemi stają się wtedy szczególnie bolesne. Na równi z robotnikami odczuwający w ten sposób bezdroża kapitalizmu chłopi i drobnomieszczaństwo przekształcają się - rzecz nieznana w krajach bogatych - w żywioł rewolucyjny" (Landau 1939b: 24). Landau, jeden z najbardziej uznanych statystyków-ekonomistów Polski międzywojennej, poza oficjalnym obiegiem wydający swoje marksistowskie diagnozy kapitalizmu pod pseudonimem „Lipski” i „St. E. J.”, wieszczył zbliżającą się wojnę jako konflikt imperializmów: agresywną odpowiedź na „groźbę nabrzmiewającego przewrotu w postaci dwóch rewolucyj: proletariackiej i agrarnej" (tamże).

W tych gorących czasach Landau - zwykle metodyczny, pieczołowity, chowający swój polityczny temperament za językiem cyfr i tabel statystycznych - pisał wprost o nadchodzącej wojnie i o fałszywej świadomości lat 30.: „nienawiści do narodów - faszyzmie”. Kilka miesięcy później zaczął

\footnotetext{
1 Teoretyczne inspiracje, które stoją za historycznym rozbiorem ostatniego przedwojennego dzieła Ludwika Landaua można podzielić na dwa rodzaje. Pierwszy to historia i filozofia współczesnej myśli statystycznej i szerzej, taksonomii naukowych (Desrosières 1998, Foucault 2005); drugi to semantyka historyczna, zwana także historia pojęć, tzw. Begriffsgeschichte (Koselleck 2001). Dla zrozumienia wpływu luksemburgizmu i teorii kryzysu kapitalizmu na polską myśli ekonomiczna w Polsce nieocenione jest opracowanie Tadeusza Kowalika (2012).

Dziękuję serdecznie anonimowym recenzentom za cenne uwagi.
} 
pisać - językiem oszczędnym, ale może przez to bardziej przejmującym - swoja słynną Kronikę lat wojny i okupacji, której już nigdy nie dokończył z powodu tragicznej śmierci w czasie Holokaustu (por. wstęp w Landau 1957, Kula 1962).

Dla Ludwika Landaua, który w latach 20. i 30. był ważna postacia Głównego Urzędu Statystycznego i współpracujących z nim Instytutu Badania Koniunktur Gospodarczych i Cen oraz Instytutu Gospodarstwa Społecznego, statystyka i polityka były nierozłączne. Tak było też w przypadku pracy statystycznej poświęconej „bezdrożom kapitalizmu”, obszarom rolniczej Europy, Afryki, Azji i Ameryki Łacińskiej, które były wówczas słabo opisane statystycznie. Opublikowana w 1939 roku przez Instytut Gospodarstwa Społecznego z przedmową Ludwika Krzywickiego Gospodarka światowa. Produkecja i dochód spoteczny w liç̨ach miała na celu stworzenie syntetycznego obrazu różnic rozwojowych pomiędzy gospodarczymi regionami świata. Ta „ryzykowna próba”, oparta w dużej mierze na szacunkach, obejmowała wszystkie obszary świata - suwerenne, ale i kolonialne - miała na celu, jak dodaje Ludwik Krzywicki, „umiejscowienie społeczeństw, w tej liczbie Polski, według skali dostrzeganego rozwoju” (Krzywicki 1939: V). Jednak polityczną stawką tej pracy był argument na rzecz uprzemysłowienia Polski: dane zebrane ze wszystkich stron świata wskazywały na to, że to nie klasyczny ricardiański międzynarodowy podział pracy zapewnia materialny dobrobyt, lecz właśnie strukturalna przemiana z obszaru opartego na drobnej własności rolnej i rzemieślniczej w kraj zbudowany na przemyśle mogłaby pomóc Polsce wejść do grupy krajów o wysokim standardzie życia.

W latach 30. argumenty za uprzemysłowieniem nie były wcale tak donośne, jak nam się dziś wydaje. Mimo że Centralny Okręg Przemysłowy oraz Gdynia były propagandowym i materialnym symbolem nowoczesności (zarówno wedle sanacyjnej władzy, jak i według powojennej historiografii), Druga Rzeczpospolita określała się na arenie międzynarodowej jako kraj emigrancki i typowo rolniczy (Bashford 2014: 77-78). Aby zobrazować ekonomiczny status Polski w świecie i pożądany kierunek jej rozwoju, Landau kładł nacisk na kwestię gospodarczego upośledzenia krajów nieprzemysłowych. Operacji tej dokonał dzięki dwóm zabiegom. Po pierwsze, zgrupował kraje świata na skali rozwoju gospodarczego, tj. uczestnictwa w przemysłowej gospodarce kapitalistycznej. Wyodrębnił zatem kraje „na wysokim poziomie gospodarki kapitalistycznej” - cała Europę Zachodnią i Środkowa, a poza nią także Stany Zjednoczone, Kanadę, Argentynę, Australię i Nową Zelandię. Pośrodku skali, w gronie krajów

\section{/ 128 STANRZECZY 1[10]/2016}


o „przejściowej strukturze”, umieścił Włochy i Japonię, czyli dwa kraje agresywnie wówczas realizujące cele kolonialnie i militarne. W trzeciej grupie „krajów częściowo objętych gospodarką kapitalistyczną” znalazła się Polska, ale nie jako osobne państwo narodowe, lecz jako gospodarka należąca do grupy krajów rolniczych Europy Wschodniej i Południowej: krajów nadbałtyckich, Węgier, Rumunii, krajów bałkańskich, Hiszpanii i Portugalii. To te właśnie kraje Landau obrazowo nazwał krajami „bezdroży kapitalizmu”. Poza tą częścią Europy autor Kroniki wojny i okupacji zaliczył do tej grupy Amerykę Środkowa i Południowa, Indie, Chiny, inne kraje azjatyckie, Oceanię i całą Afrykę. Po drugie, Landau podkreślał, że europejskie i pozaeuropejskie kraje, znajdujące się na obrzeżach przemysłowego kapitalizmu, stanowiły - nie bagatela - „dwie trzecie całej ludzkości” (Landau 1957: 359). Dla demokraty-socjalisty, jakim był Landau, los upośledzonych mas, w tym wypadku demograficznej większości świata, był politycznie kluczowy. Świadczą o tym jego wspomniane już publikacje polityczne, które diagnozowały ubóstwo Europy Wschodniej, Afryki, Azji i Ameryki Łacińskiej jako wspólny międzykontynentalny problem i umieszczały tam ognisko zapalne światowych konfliktów zbrojnych i ideologicznych.

A zatem, Polska i szerzej „rolnicza Europa” stanowiły na skali Landaua swego rodzaju teren pośredni, dwoisty, łączący na jednym obszarze zjawiska gospodarcze charakterystyczne zarówno dla Europy, jak i Afryki, Azji i Ameryki Lacińskiej. Przypisując szczególne znaczenie obszarom półprzemysłowym oraz nieuprzemysłowionym, Landau podkreślał tym samym nieoczywistość i nieostrość granic społeczno-gospodarczych między Europą Wschodnią a Afryką, Azją i Ameryką Lacińską (z wyjątkiem Argentyny i szczególnego przypadku Związku Radzieckiego). Tłumaczył, że znajdując się w polu oddziaływania rynków kapitalistycznych, przeważająca większość ludności krajów rolniczych - zarówno w Europie, jak i poza nią - była w dużej mierze wyłączona z podziału renty i zysków inwestycyjnych, czyli z podziału lwiej części kapitalistycznego tortu. Wielu makroekonomistów, z Landauem na czele, określało to zjawisko mianem światowego „podziału dochodu społecznego”. Dziś mówilibyśmy w tym miejscu o globalnych nierównościach społecznych. „Te rażquce stosunki - pisał Landau - zjawiaja sie, gdy przechodzimy do ludności rolniczej $i$ zwiazanych z nia grup - rzemiosła i handlu wiejskiego, małomiasteczkowego itd.: «tuશiemcón»» w krajach w ścistym żnaczenin kolonialnych lub bedacych w takim samym poto:ंeniu chlopón (oraz rzemieślników, drobnych kupcón itd.), w rolniçych krajach Europy" (Landau 1957: 423) (podkr. aut.). Różnice w produkcji przemysłowej 
między Indiami a Stanami Zjednoczonymi Landau szacował w 1939 roku w stosunku liczbowym 1:80 (Landau 1939a: 149).

Szkic ten ma na celu wstępne odczytanie - z punktu widzenia historii wiedzy i historii intelektualnej - fascynującej i nowatorskiej mapy Landaua, która wpisuje się w dwudziestowieczne i współczesne debaty o strukturalnym miejscu Polski w gospodarce światowej. Poniżej przedstawiam, jak w dziele statystycznym Landaua zbiegły się dwie epistemologiczne ścieżki, kluczowe dla zrozumienia ekonomii i geografii politycznej lat międzywojennych. Pierwszą inspiracją był środkowo- i wschodnioeuropejski marksizm i prowadzone w tym paradygmacie dyskusje o światowym kapitalizmie - jego granicach geograficznych, politycznych oraz przebiegu ekspansji w XIX i na początku XX wieku (imperializm). To właśnie marksizm w połączeniu z naukami społecznymi, rozwijany w tej synkretycznej formie przez bliskich kolegów i nauczycieli Landaua - Ludwika Krzywickiego, Oskara Langego, Michała Kaleckiego - ukształtowały polityczno-ekonomiczne i geograficzne rozumienie Polski jako przestrzeni „półkapitalizmu”. Drugą ścieżkę poznawczą stanowiła standardowa wiedza statystyczna, zwana inaczej statystyka porównawcza, która ugruntowała w naukach społecznych i ekonomicznych pojęcie „rolniczej Europy” i inne kategorie międzynarodowej statystyki gospodarczej lat 20. i 30. XX w.

Określenie „bezdroża kapitalizmu” pochodzi ze słownika marksizmu, a ściślej marksistowskiej refleksji o imperializmie końca XIX i początku XX w. Refleksja ta ugruntowała w ówczesnych naukach społecznych analizę strukturalistyczną. Strukturalizm tamtej epoki zawierał również ślady pozytywistycznego organicyzmu (organizm jako struktura) i z czasem zaczął funkcjonować wśród uczonych niemarksistów (Riedel 1990). W międzywojniu rolnicze tereny Europy Południowej i Wschodniej opisywano strukturalnie jako rezerwuar taniej i łatwo zastępowalnej siły roboczej oraz środowisko jej brutalnej eksploatacji. Tereny pogranicza kapitalizmu, zdaniem wschodnioeuropejskich i kolonialnych ekonomistów, cechowały się tzw. dualizmem ekonomicznym wewnątrz poszczególnych obszarów gospodarczych: kolonialnych, regionalnych czy wreszcie narodowych. Elementami tej struktury były sztywny podział na zurbanizowane centrum i wiejskie peryferie, a także zależność od zagranicznego lub metropolitarnego kapitału i wysokie ryzyko inwestycji (Landau 1939b, Love 1997, Boeke 1953). Dualizm gospodarczy był główną cechą gospodarek, które Landau sklasyfikował jako „częściowo objęte gospodarką kapitalistyczną”. Kontrast gospodarczy, który uwidoczniał się na styku obszarów kapitali- 
stycznych i niekapitalistycznych, widziano w tym czasie już w skali całego globu.

Zgodnie z myślą Róży Luksemburg i innych marksistowskich teoretyków kapitalizm był systemem ekspansywnym. „Produkcja kapitalistyczna, tak pod względem swych form, jak i praw rozwoju, od samego zarania obliczona jest na całą kulę ziemską jako skarbnicę sił wytwórczych". (Luksemburg 2011: 442). Polemiści Róży Luksemburg - Rudolf Hilferding, Nikołaj Bucharin i przede wszystkim Włodzimierz Iljicz Lenin zapowiadali całkowity podział świata przez międzynarodowy kapitał, a w konsekwencji dotarcie do geograficznych i gospodarczych granic kapitalistycznej ekspansji (Hilferding 1910, Bucharin 1918, Lenin 1920). Dla Ludwika Landaua i całego grona radykalnej warszawskiej inteligencji lat 20. głównym źródłem inspiracji w rozważaniach o światowym kapitalizmie była niewątpliwie sama Róża Luksemburg (Kowalik 2012). Z jej ekonomii politycznej imperializmu czerpał Michał Kalecki (Toporowski 2013: 46-47), najbliższy współpracownik Landaua w latach 30. Główny zaś bibliograficzny przewodnik po marksistowskiej ekonomii politycznej z 1931 r., stworzony przez zespół lewicy PPS pod kierownictwem Oskara Langego, otwierał cytat z najsłynniejszego dzieła Róży Luksemburg, Akumulacji kapitału (Lange, Malinowski 1931). Jest przy tym jasne, że ze względu na sanacyjną cenzurę oficjalne odwołania do literatury marksistowskiej były nie do pomyślenia. Zasada ta tym bardziej obowiązywała pracowników państwowej instytucji GUS-u, do których zaliczał się Landau². A jednak główna myśl Róży Luksemburg, że proces akumulacji należy badać „w rzeczywiście istniejących warunkach historycznych - jako rozwój kapitalistyczny, pozostający w stałych wzajemnych stosunkach ze środowiskiem niekapitalistycznym" (Luksemburg 2011: 687), wyznaczyła intelektualny horyzont Gospodarki swiatowej.

Klasyfikację gospodarczych regionów świata Landaua z 1939 roku można by wręcz odczytać jako statystyczną konkretyzację dzieła Róży Luksemburg. Jej rozważania na temat granicznych obszarów kapitalistycznego uprzemysłowienia można śledzić już w pierwszej opublikowanej pracy o rozwoju przemysłowym Polski (Luksemburg 1957). Ale rewelacją wśród polskiej radykalnej lewicy lat międzywojnia (lewe skrzydło PPS, Bund, Komunistyczna Partia Polski) i jej ekonomicznych ekspertów był jeden z fragmentów Akumulacji kapitatu pt. Reprodukecja kapitału i jej środowisko spoteczne

\footnotetext{
${ }^{2}$ O cenzurze politycznej i politycznych czystkach kadrowych w międzywojennym Głównym Urzędzie Statystycznym wiemy niewiele. Wzmianki na ten temat znajdują się w literaturze wspomnieniowej i w aktach komisarza rządu na m.st. Warszawę, który sprawował polityczno-policyjny nadzór nad GUS-em.
} 
(Luksemburg 2011). W rozdziale tym Luksemburg przedstawiła własne, bo oparte na obserwacjach z kraju urodzenia, spojrzenie na wiejskie, zacofane obszary przechodzące transformację kapitalistyczna. Przez „środowisko społeczne" tzw. geograficznej ekspansji rynkowej Luksemburg rozumiała obszary niekapitalistyczne. Zgodnie z tym poglądem ówczesna akumulacja kapitału odbywała się przede wszystkim na krańcach uprzemysłowionego świata: w Europie Wschodniej, Chinach, Rosji, w miejscach, które Luksemburg określiła mianem globalnego „wschodu” i „południa”. Była to uwspółcześniona reinterpretacja Marksowskiej, pierwotnej akumulacji (Luksemburg 2011: 343). Polegała na geograficznej redefinicji „środowiska społecznego", w którym domyślnie miała dokonywać się Marksowska akumulacja i reprodukcja kapitału. W klasycznym, dziewiętnastowiecznym ujęciu była nim Anglia: proces jej uprzemysłowienia i na marginesie - ekspansja kolonialna ${ }^{3}$. Tymczasem to, co u Marksa stanowiło geograficzne krańce kapitalistycznej produkcji - „rynki zewnętrzne” - u Luksemburg było przestrzennym i politycznym trzonem całego schematu odtwarzania i rozwoju kapitalizmu. Rolnicze zacofanie i chłopska gospodarka „przetrwania”, które charakteryzowały globalny Wschód i Południe, zostały w ten sposób wyniesione na pierwszy plan ekonomii politycznej. „Kraje częściowo objęte gospodarką kapitalistyczną”, wyszczególnione przez Landaua, były więc odpowiednikiem obszarów, które Luksemburg nazywała światowym Wschodem i Południem. Tam właśnie kapitalizm przenikał i żywił się gospodarką chłopską, drobnotowarową lub ,prymitywnymi systemami eksploatacji [...] stanowiącymi różnorakie kombinacje stosunków niewolniczych i pańszczyźnianych" (Luksemburg 2011: 442).

Kiedy Akumulacja kapitału Róży Luksemburg stała się przedmiotem sporów o przyszłość kapitalizmu, nowo ukonstytuowane państwa narodowe Europy Środkowo-Wschodniej przeprowadzały etniczna, społeczną i ekonomiczną inwentaryzację lokalnych zasobów i ludności. W Drugiej Rzeczypospolitej, państwie zlepionym z fragmentów rosyjskiego, niemieckiego i austro-węgierskiego imperium, statystyka stała się narzędziem politycznej i epistemologicznej unifikacji. Ludwik Landau był kluczową postacią tych statystyczno-administracyjnych przedsięwzięć. Przy pomocy metodologicznego strukturalizmu, marksistowskiej ekonomii politycznej i warsztatu statystycznego szukał odpowiedzi na pytanie, jakiego rodzaju obszarem gospodarczym i społecznym było młode państwo polskie.

\footnotetext{
${ }^{3}$ Marksowska teoria schematów reprodukcji kapitalizmu skupiała się przede wszystkim na tym, co Luksemburg nazywała ogólnie „krajami strefy umiarkowanej”, w których kapitalistyczna wytwórczość dokonywała się przy użyciu „białej siły roboczej” (Luksemburg 2003: 343).
} 
Język cyfr był w okresie międzywojennym uznawany za mowę nowoczesnej nauki, stąd też waga, jaką w polityce krajowej odgrywały prace statystyczne i ich sposób objaśniania świata. Świadczy o tym popularność wydawanego przez Główny Urząd Statystyczny Matego Rocznika Statystycznego. W latach 30. stał się on jedną z najpoczytniejszych krajowych publikacji. W 1939 roku jego sprzedaż sięgnęła 100 tys. egzemplarzy (Szturm de Sztrem 1939: V). Zaangażowanie Landaua w sukces „Małego Rocznika” i ogólniej, w rozwój statystyki jako języka społecznego i gospodarczego samopoznania było bezprecedensowe. Pierwsze obliczenia, zawarte w Gospodarce światowej, publikowane były właśnie na masową skalę w słynnym „Małym Roczniku”, a ich wymowa była wtedy jasna - Polska była biednym krajem o niskim poziomie życia, charakteryzującym przede wszystkim ludność wsi i miasteczek. Syntetyczny i przedstawiony w szerokim geograficznym kontekście obraz Polski, zawarty w „Małym Roczniku”, miał zatem moc polityczno-ekonomicznej diagnozy, którą wykorzystywały rywalizujące ze sobą obozy polityczne Drugiej Rzeczypospolitej

Statystyka była zatem zarówno kolejnym źródłem wiedzy, jak i językiem politycznej prawomocności, którym posługiwał się Ludwik Landau. Od związków między nauką a polityką nie były wolne pozornie bezstronne geograficzne klasyfikacje, które znajdujemy w tabelach statystycznych Gospodarki światowej. Należało do nich na przykład pojęcie „,rolniczej Europy”, nazwa, która pojawiła się w międzynarodowych klasyfikacjach statystycznych Ligi Narodów i Międzynarodowej Organizacji Pracy na początku lat 30. (Warriner 1953). W latach 30. pod terminem ,rolnicza Europa” rozumiano wschód i południe kontynentu, w tym Bałkany, Hiszpanię, Włochy, Portugalię. Polska była również jej typowym przykładem. Samo określenie wyłoniło się z debat eksperckich, toczących się na łamach międzynarodowych publikacji statystycznych (Delaisi 1929, Ribi Forclaz 2011). Pojęcie „rolnicza Europa” przyjęło się też na wschodzie Europy, gdzie toczyły się intensywne dyskusje na temat przyszłości kapitalizmu, polityki ludnościowej i handlu międzynarodowego. Kwestie te miejscowi uczeni uznali w międzywojniu za kluczowe dla przyszłego rozwoju Europy Wschodniej i Południowo-Wschodniej.

Choć Landau traktował z dystansem pojęcia i szacunki statystyczne Ligi Narodów i standardy międzynarodowej statystyki, które ustalane były głównie na Zachodzie, były one jednak dla niego punktem odniesienia,

\footnotetext{
${ }^{4}$ Warto przy tym dodać, że Główny Urząd Statystyczny, duża instytucja cierpiąca na brak wykształconych kadr, była naukowym i politycznym azylem dla wielu lewicowych aktywistów, którzy podobnie jak Landau funkcjonowali na marginesie ówczesnej nauki akademickiej (Grzybek 2012).
} 
jak choćby przeniesiona z międzynarodowej nomenklatury kategoria „rolniczej Europy". Wskazuje na to fakt, że w Gospodarce światowej Landau ani razu nie użył określenia „Europa Wschodnia” bądź „Europa Środkowo-Wschodnia”. Zamiast tego mówił o „rolniczej Europie”. Taksonomia ludzi i miejsc, która krążyła w Genewie (Liga Narodów i Międzynarodowa Organizacja Pracy) i na zachodzie Europy, znalazła zatem ślad w języku statystycznym używanym przez Landaua (Landau 1939c), choć jego autorska wersja ekonomii politycznej świata była bliska przede wszystkim tradycji marksistowskiej.

Historia pojęcia „rolniczej Europy” wiąże się z przestrzenną rekonfiguracją kwestii dualizmu ekonomicznego. Zamiast strukturalnych dysproporcji wewnatrz. Europy Wschodniej i Południowej lub wewnatrz imperiów kolonialnych, „rolnicza Europa” wskazywała na podział kontynentalny: przemysłowy Zachód i rolniczy Wschód. To stricte terytorialne ujęcie tematu upowszechniło się w międzynarodowych kręgach ekspertów dość późno, bo we wczesnych latach $30 .{ }^{5} \mathrm{~W}$ poprzedniej dekadzie o Europie Wschodniej i Południowo-Wschodniej, zniszczonej pierwszą wojną światowa, epidemiami i hiperinflacją, mówiono prawie wyłącznie pod kątem interwencji humanitarnej lub monetarnej (np. pożyczek międzynarodowych). Ludność wiejska tego regionu pojawiała się w kontekście zagrożenia rewolucyjnego, epidemiologicznego i sanitarnego. Próby statystycznego sklasyfikowania ludności wiejskiej Europy Wschodniej i Południowej ${ }^{6}$ oraz uczynienia jej widoczną w statystykach międzynarodowych poniosły wówczas porażkę. Zachodni eksperci uważali, że obszary wiejskie w świecie nieuprzemysłowionym były zbyt odległe kulturowo i gospodarczo niejednolite, by mogły zostać ujęte w standardy międzynarodowej statystyki (Ribi Forclaz 2011: 307-329, 315).

Kiedy Wielki Kryzys (1929-1935) drastycznie pogorszył sytuację w rolniczych obszarach świata, zubożona „rolnicza Europa” zaczęła być postrzegana nie tylko jako obszar zacofania, ale również jako ogólny prototyp agrarnych i ,zapadniętych gospodarczo” (depressed areas) regionów świa-

\footnotetext{
${ }^{5}$ Podział na „nowoczesną” Europę Zachodnią i „zacofaną” Europę Wschodnią wiąże się z okresem oświecenia i funkcjonował też w publicystyce i nauce dziewiętnastowiecznej. W tym przypadku moje rozważania ograniczają się wyłącznie do eksperckiego dyskursu organizacji międzynarodowych w okresie międzywojennym, który zmienił się radykalnie między pierwszą a drugą dekadą międzywojnia.

${ }^{6}$ Problem z klasyfikacją ludności wiejskiej wiązał się także z trudnościami w zdefiniowaniu wsi (w Polsce, na przykład, wiele miasteczek mających prawny status miasta w rzeczywistości było wsiami). Roczniki „narodowe” podawały, że ludność miejska i miast liczyła powyżej 10 tys. mieszkańców. W porównaniach międzynarodowych istniała natomiast kategoria „ludność utrzymująca się z rolnictwa”. Za tę uwagę dziękuję anonimowemu recenzentowi.
} 
ta (Warriner 1953: 168-186, Clavin 2013, Rosenstein-Rodan 1944: 157165). W 1935 roku w Genewie ruszyły pierwsze międzynarodowe badania nad życiem na wsi w rolniczej Europie i innych częściach niezachodniego świata. Dominowało modne wówczas podejście terytorialno-demograficzne i antropologiczne, dyskutowane w kategoriach ,przeludnienia na wsi”, „,bezpieczeństwa żywieniowego” oraz „higieny wiejskiej”.

Termin „rolnicza Europa”, utwierdzający dychotomiczne postrzeganie kontynentu, ukształtował się zatem $\mathrm{w}$ procesie semantycznego uproszczenia. Tereny, które jeszcze kilka lat wcześniej uznawano za mozaikowe i nieporównywalne z cywilizacja Zachodu, w latach trzydziestych opisywano jedna, prostą nazwą, sprowadzającą wszystkie problemy Europy Wschodniej i Południowej do zubożałej gospodarki chłopskiej. Proces tej nazewniczej redukcji zainicjowała ksiażka Francisa Delaisiego pod tytułem Les deux Europes (Dwie Europy) z 1929 roku. Dzieląc zgodnie z metaforyką hippiczną kontynent europejski na Zachód, oparty na energii koni mechanicznych (cheval vapeur), i Wschód, oparty na sile koni pociągowych (cheval trait), Delaisi forsował utrwalenie wewnątrzkontynentalnego podziału pracy. Wizja dwóch Europ zyskała duże zainteresowanie w anglo-amerykańskich i liberalnych kołach Ligi Narodów, gdzie obawiano się, że uprzemysłowienie globalnego Wschodu i Południa podważy gospodarczą przewagę Zachodu, polegającą na wywozie artykułów przemysłowych i imporcie tanich surowców mineralnych i rolniczych z tzw. reszty świata ${ }^{7}$. Książka Delaisiego zrobiła karierę w Genewie i Londynie lat 30., gdzie dyskutowały ja eksperckie gremia robocze i think-tanki, a następnie eksperci tworzący międzynarodową nomenklaturę statystyczną. Była to droga (choć z pewnością nie była ona jedyna), dzięki której podział Europy na przemysłowy Zachód i rolniczy Wschód zyskał nowe znaczenie, tym razem w kontekście gospodarczych dyskusji o międzynarodowym podziale pracy. W 1939 roku, kiedy Landau wydał swoją statystyczną syntezę światowej gospodarki, „rolnicza Europa” była już międzynarodowo ugruntowanym konceptem oznaczającym obszar zamieszkały przez „dużą ilość ludzi, pracujących na małych, prywatnych działkach ziemi, w gęsto zaludnionym obszarze" (Clavin 2013: 198).

Landau był zmuszony zmierzyć się z tym upraszczającym, a jednocześnie politycznie wpływowym wyobrażeniem Europy, które stało się

\footnotetext{
7 W latach 30. dyskusje i działania na rzecz agraryzacji krajów uprzemysłowionych i uprzemysłowienia krajów rolniczych zdominowały politykę europejskich państw narodowych, które nie oglądając się na interesy anglo-amerykańskie, dążyły do samowystarczalności gospodarczej i aprowizacyjnej na wypadek nowej wojny.
} 
powszechne wśród ówczesnych międzynarodowych ekspertów gospodarczych. Kiedy pisał o „rolniczej Europie”, to uwzględniając jej pierwotny geograficzny zasięg, nadawal jej sens pochodzący z nieco starszych debat o ekonomii politycznej rubieży czy też bezdroży kapitalizmu. Koncepcja Europy Wschodniej i Południowej jako odrębnego obszaru gospodarczego powstawała tym samym w różnych obiegach wiedzy eksperckiej i politycznej: wśród marksistów, zachodnich liberałów, ricardiańskich konserwatystów i wreszcie, wśród ekspertów od międzynarodowej standaryzacji statystyki. Skoro w pracy Landaua za podstawowymi pojęciami, jak ,gospodarka światowa” czy „rolnicza Europa”, kryły się wielowątkowe i rozgałęzione historie pojęć i kategorii wiedzy; podobne semiotyczne embarras de richesse dotyczyło innych elementarnych terminów, takich jak ,gospodarka chłopska”, „bezrobocie” czy wreszcie samo pojęcie rozwoju gospodarczego. Historia ekonomicznej konceptualizacji Polski i Europy Wschodniej, rozumianej raz jako część liberalno-konserwatywnej wizji „,rolniczej Europy”, a raz jako element marksistowskiej wizji kapitalizmu, pozwala zrozumieć, w jaki sposób Ludwik Landau - typ „lokalnego uczonego” z międzynarodowymi kontaktami i zapleczem intelektualnym - składał w całość konkurujące, współistniejące i nakładające się na siebie epistemologie.

Landau wykonywał w dziedzinie statystyki porównawczej i gospodarczej podobna pracę - czyli geograficzne rozszerzenie i przekształcenie podstawowych kategorii wiedzy - jaką dla ekonomii politycznej wykonała Róża Luksemburg. Prowadząc żmudne obliczenia statystyczne, Landau doszedł na przykład do wniosku, że większość wskaźników publikowanych przez Ligę Narodów i najważniejszy w Europie ośrodek statystyczny, Niemiecki Urząd Statystyczny, skrojona była na miarę gospodarek przemysłowych. Odzwierciedlały przede wszystkim współczesny ekosystem wielkoprzemysłowych koncernów i wielkomiejskiej klasy robotniczej. Ten nowoczesny aparat pojęciowy, a zarazem punkt odniesienia dla międzynarodowych badań statystycznych, nie uwzględniał i nie mierzył specyficznego sposobu wytwórczości i konsumpcji w krajach nieuprzemysłowionych. Ówczesna międzynarodowa, czyli de facto zachodnia statystyka, nie odnotowywała chociażby zjawiska, które Ludwik Landau nazwał w 1939 „ukrytym bezrobociem na wsi" (Landau, Pański, Strzelecki 1939). Bezrobocie było wówczas kategoria przypisaną do zurbanizowanych, pieniężnych gospodarek w krajach, które od XIX wieku tworzyły zręby systemu zabezpieczenia socjalnego dla pracowników najemnych. Jeszcze w latach 30. praca chłopów była całkowicie wykluczona z rozważań nowoczesnej statystyki pracy. 
Tymczasem w Drugiej Rzeczypospolitej chłopi stanowili większość mieszkańców przekraczającą sześćdziesiąt procent. W latach 30. zła sytuacja polityczno-gospodarcza na wsi powoli zaczęła być postrzegana jako zagrożenie dla bezpieczeństwa kraju. Niedożywiony chłop jako potencjalny rekrut do wojska, rewolucjonista/partyzant lub wiejski mieszkaniec Ziem Wschodnich oporny na zabiegi polonizacyjno-asymilacyjne: wszystkie te odsłony polskiej wsi mogły stanowić potencjalne zagrożenie dla sanacyjnego raison d'État. Co więcej, w okresie międzywojennym na analizę środowisk wiejskich ogromny wpływ miały nauki demograficzne i geograficzne, które definiowały problemy społeczne europejskiego Wschodu oraz Południa jako problem przeludnienia. W przypadku Polski teorie tzw. przeludnienia na wsi usprawiedliwiały politykę emigracyjną względem chłopów i mniejszości narodowych. Usprawiedliwiały też antysemityzm jako rzekomo obiektywnie istniejący efekt presji demograficznej, wywołującej antagonizmy etniczne. Pod koniec lat 30. sanacja z poparciem Stronnictwa Ludowego i endecji forsowały prawnie i poprzez międzynarodowe zabiegi dyplomatyczne tezę, że „nadwyżkami ludności” są przede wszystkimi mniejszości etniczne (Esch 1998). Ich wyjazd z Polski miał stworzyć miejsca pracy dla etnicznych Polaków i umożliwić tym samym rozwój gospodarki narodowej, pojęcie, które polskie elity rządzące rozumiały etnicznie (Ormicki 1937, Friszke 1989) ${ }^{8}$.

Ku niepokojowi Landaua popularność, a wręcz wszechobecność dyskursu o przeludnieniu odwracała uwagę opinii publicznej od społeczno-gospodarczych problemów ludności wiejskiej. Problem tkwił w samej istocie kapitalizmu, a nie w narodowym składzie państwa polskiego, twierdził Landau i jego polityczni sprzymierzeńcy - PPS i Bund. Obszary półkapitalistyczne zdaniem Landaua potrzebowały nie tyle rozbudowanego programu emigracyjno-kolonizacyjnego, ile wejścia na ścieżkę rozwoju przemysłowego i planowego socjalizmu, w którym podziały etniczne nie miały znaczenia. Kosmopolityczny rozmach Gospodarki swiatowej kontrastował z antysemicką kampanią prasową, którą przeciwko Landauowi zainicjował „Goniec Warszawski” pod koniec lat 30.

Podsumowując, Gospodarka światowa wychodziła wprost z pesymistycznej wizja gospodarki światowej jako obszaru kapitalistycznej ekspansji, ergo generującej katastrofy gospodarcze i kryzysy. Dzięki marksistowskim koncepcjom gospodarki światowej, które rozwijały się od końca XIX wieku do lat 30. XX wieku w Europie Środkowej i Wschodniej, kwestia kapita-

\footnotetext{
${ }^{8}$ Najciekawsze podsumowanie polskiej dyskusji o przeludnieniu znajduje się w polemicznej pracy jednego z głównych działaczy Bundu, zob.: Alter 1937; Esch 1998.
} 
listycznych bezdroży stała się ośrodkiem zainteresowania ekonomii politycznej. Landau, zainspirowany zarówno marksizmem, jak i rodzącą się makroekonomią oraz socjologią, przeniósł te wywrotowe treści z dziedziny marksistowskiej ekonomii politycznej na grunt nowoczesnej statystyki porównawczej. Umiejscawiając rolniczą Europę w centrum prowadzonych obliczeń statystycznych, Landau mógł wyodrębnić specyficzne problemy gospodarek zwanych wówczas „półkapitalistycznymi”. „Rolnicza Europa” stanowiła w tym kontekście obszar, dziś pewnie powiedzielibyśmy: hybrydalna przestrzeń, w której kapitalizm wielkich koncernów i karteli oddziaływał i współwystępował z tzw. przeżytkami przed- i pozakapitalistycznych struktur(Love 1997: 159).

Nowoczesna wiedza o „półkapitalizmie”, wywodząca się z Europy Wschodniej i Południowo-Wschodniej, zaczęła krążyć po świecie jeszcze przed wybuchem drugiej wojny światowej. Strukturalne teorie gospodarczego zacofania, które powstały w tym samym czasie w Rumunii, promieniowały do Ameryki Łacińskiej (Love 1997). Organizacje międzynarodowe odczytywały tę fachową wiedzę na temat chłopskiej i rolniczej Europy przez pryzmat jej przydatności w innych, niezachodnich częściach świata, np. w Chinach czy Indiach (Amrith, Clavin 2013). Pod koniec lat 30. zachodnie kręgi intelektualne dostrzegły w „kwestii chłopskiej”, tak dobrze znanej ze wschodnioeuropejskiego podwórka, nową kwestię społeczna, która miała globalny wymiar. Stworzyło to zapotrzebowanie na fakty i dane na temat świata niezachodniego. Wschodnioeuropejscy uczeni, dyżurni specjaliści od tematyki „zacofania”, umieli dostarczyć je w formie, która była zrozumiała dla zachodniego odbiorcy: urzędnika Ligi Narodów lub brytyjskiego polityka.

W latach 30. gospodarcze upośledzenie czy też biedę „bezdroży kapitalizmu" coraz częściej starano się ujmować za pomocą syntetycznych wskaźników. Do tego instrumentarium nowoczesnych nauk społecznych należały między innymi pomiary produkcji i dochodu poszczególnych państw i regionów świata. Landau nie był jedynym uczonym, który pracował nad światowa mapa dochodu społecznego. W tym samym czasie australijski ekonomista Colin Clark opracował międzynarodowe porównanie dochodu narodowego'. Oba przedsięwzięcia miały na celu swoistą dekolonizację czy też upodmiotowienie świata niezachodniego za pomocą metod ilościowych i ekonomicznych abstrakcji. Cyfry tworzyły tam wspólną skalę porównawczą dla wszystkich części globu. Landau i Clark posługiwali się

9 Na temat badań Colina Clarka w kontekście historii dochodu narodowego brutto, tzw. PKB, zob. Speich Chassé 2011, 2013. 
nimi globalnie, wbrew powszechnemu wówczas przekonaniu, że różnice kulturowe między Zachodem a resztą świata były zbyt duże, bo stosować wobec nich jedną miarę opisu. W Gospodarce światowej Landau udowodnił, że można ując statystycznie, a więc opisać językiem nowoczesności, obszary uznawane wówczas za „zacofane”. Stworzył tym samym rodzaj statystycznego uniwersalizmu, który dzięki koncepcjom i technikom opracowanym dla opisania dualistycznej struktury gospodarczej Drugiej Rzeczypospolitej (potocznie zawarty w haśle „Polski A” i „Polski B”) scalił różne części świata. Wprowadzeniem statystycznej porównywalności między krajami zachodniej cywilizacji a tzw. resztą świata Landau podważył przekonanie o ich fundamentalnej, bo kulturowej, nieprzystawalności.

Wpływ intelektualny Landaua na kolegów ekonomistów zajmujących się tematyką rozwoju (Michała Kaleckiego, Pawła Rosensteina-Rodana czy też Oskara Langego) pozostał nieznany w świecie z powodu jego tragicznej śmierci podczas Holokaustu. Wiemy, że Kalecki napisał prawdopodobnie jedyną anglojęzyczną recenzję Gospodarki światowej. Z pewnością badania Landaua były znane w Londynie, gdzie w czasie drugiej wojny światowej problemy Polski i rolniczej Europy były żywo dyskutowane jako parabola globalnej kwestii agrarnej (Kalecki 1939). W 1939 Ludwik Krzywicki nawoływał do opublikowania pracy w jednym z języków światowych, tak by przyczynek Landaua, jego ,ujęcie dążności we wszechświatowym obrazie produkcji” i „opóźnień rozwojowych” stał się „pobudką do pogłębienia działalności urzędów statystycznych" w innych krajach (Krzywicki 1939: VII). Do świadomości międzynarodowej opinii publicznej przedostała się jednak tylko anglojęzyczna praca Colina Clarka (1940) i to ona właśnie została uznana na Zachodzie za pierwszą próbę zmierzenia globalnych nierówności (Speich Chassé 2013).

Współpraca przy przekładzie: Artur Banaszewski

Bibliografia:

/// Alter W. 1937. Antysemityzm gospodarçy w świetle cyfr, Wydawnictwo „Myśli Socjalistycznej”"

/// Amrith S., Clavin P. 2013. Feeding the World: Connecting Europe and Asia, 1930-1945, „Past and Present”, Supplement 8, s. 29-50. 
/// Bashford A. 2014. Global Population. History, Geopolitics, and Life on Earth, Columbia University Press.

/// Boeke J.H. 1953. Economics and Economic Policy of Dual Societies, as Exemplified by Indonesia, International Secretariat of the Institute of Pacific Relations.

/// Bucharin N. 1918. Mirowoje chozjajstwo i imperializm, Priboj. [Tłum. pol.: Imperjalizm a gospodarka światowa, tłum. J. Kamieński, Bibljioteka Wiedzy Współczesnej, 1934.]

/// Clark C. 1940. The Conditions of Economic Progress, MacMillan and Co.

/// Clavin P. 2013. Securing the World Economy: The Reinvention of the League of Nations, 1920-1946, Oxford University Press.

/// Delaisi F. 1929. Les deux Europes, Payot.

/// Desrosières A. 1998. The Politics of Large Numbers. A History of Statistical Reasoning, tłum. C. Naish, Harvard University Press.

/// Esch M. 1998. Gesunde Verbältnisse. Deutsche und polnische Bevölkerungspolitik in Ostmitteleuropa 1939-1950, Herder-Institut Verlag.

/// Foucault M. 2005. Stowa i rzeczy: archeologia nauk, humanistycznych, przeł. Tadeusz Komendant, Wydawnictwo słowo/obraz terytoria.

/// Friszke A. 1989. O kesz̨tałt niepodległej, Biblioteka „Więzi”.

/// Grzybek D. 2012. Polityczne konsekwencje idei ekonomicznych w myśli polskiej 1869-1939, Księgarnia Akademicka.

/// Hilferding R. 1910. Das Finan₹keapital: eine Studie über die jüngste Entwicklung des Kapitalismus, Brand. [Tłum. pol.: Kapitał finansowy: studium o najnowszym rozwoju kapitalizmu, tłum. J. Garewicz, E. Rose, Polskie Wydawnictwo Naukowe, 1958.]

/// Kalecki M. 1939. Gospodarka światowa. Produkecja i dochód w liç̧ach by Ludwik Landau, „The Economic Journal”, t. 49, nr 195, s. 513-515.

/// Koselleck R. 2001. Semantyka historyczna, wybór i oprac. H. Orłowski, tłum. W. Kunicki, Wydawnictwo Poznańskie.

/// Kowalik T. 2012 [1971]. Róża Luksemburg. Teoria akumulacji i imperializmu, Instytut Wydawniczy Książka i Prasa. 
/// Krzywicki L. 1939. Przedmowa, [w:] L. Landau, Gospodarka światowa. Produkcja $i$ dochód społeczny w cyfrach, Instytut Gospodarstwa Społecznego, s. V-VII.

/// Kula W. 1962. Præcedmowa, [w:] L. Landau, Kronika lat wojny i okupacji, t. 1: Wrzesień 1939-listopad 1940, oprac. Z. Landau i J. Tomaszewski, Państwowe Wydawnictwo Naukowe, s. V-XII.

/// Landau L. 1939a. Gospodarka światowa. Produkecja i dochód społecrny w liczbach, Instytut Gospodarstwa Społecznego.

/// Landau L. [Wacław Lipski]. 1939b. Kapitalizm, Towarzystwo Oświaty Ludowej.

/// Landau L. 1939c. Seasonal emigration from Poland to Germany and Latvia, „International Labour Review”, nr 40, s. 195-208.

/// Landau L. 1957 [1939]. Gospodarka światowa. Produkcja i dochód spoleczny w licz̧bach, [w:] tegoż, Wybór pism, red. T. Szturm de Sztrem, Państwowe Wydawnictwo Naukowe, s. 353-426.

/// Landau L., Kalecki M. 1935. Dochód społeczny w r. 1933 i podstawy badań periodycznych nad zmianami dochodu, Instytut Badania Koniunktur Gospodarczych i Cen.

/// Landau L., Strzelecki E., Pański J. 1939. Bezrobocie wśród chłopów, Instytut Gospodarstwa Społecznego.

/// Lange O., Malinowski W. 1931. Socjalizm. Zarys bibljograficzny i metodologiczny. Praca zbiorowa, Tow. Uniwersytetu Robotniczego (TUR), Oddział im. Adama Mickiewicza.

/// Lenin W.I. 1920. Imperialismus als jüngste Etappe des Kapitalismus, Verlag der Kommunistischen Internationale. [Tłum. pol.: Imperjalizm jako najnowszy etap w rozwoju kapitalizmu: sqkic popularny, Stowarzyszenie Spółdzielcze „Książka”, 1919. Wyd. oryg.: 1917.]

/// Love J. 1997. Crafting the Third World. Theorizing Underdevelopment in Romania and Brazil, Stanford University Press.

/// Luksemburg R. 1957. Rozwój præ̧emystu w Polsce, tłum. J. Chlebowczyk, Książka i Wiedza. [Wyd. oryg.: Rosa Luxemburg, Die industrielle Entwicklung Polens, Duncker \& Humblot, 1898.] 
/// Luksemburg R. 2011. Akumulacja kapitału. Przyczynek do ekonomicznego wyjaśnienia imperializmu, tłum. J. Maliniak, Z. Kluza-Wołosiewicz, J. Nowacki, Instytut Wydawniczy „Książka i Prasa”. [Wyd. oryg.: Rosa Luxemburg, Die Akkumulation des Kapitals. Ein Beitrag zur ökonomischen Erklärung des Imperialismus, Buchhandlung Vorwärts Paul Singer, 1913.]

/// Ormicki W. 1937. Problem emigracyjny i surowcowy w Polsce, MSZ.

/// Riedel M. 1990. Struktur, System, [w:] Geschichtliche Grundbegriffe. Historisches Lexikon zur politisch-sozialen Sprache in Deutschland, red. O. Brunner, W. Conze, R. Kosseleck, tom VI, Klett-Cotta, s. 285-322.

/// Rosenstein-Rodan P. 1944. The International Development of Economically Backward Areas, „International Affairs”, t. 20, nr 2, s. 157-165.

/// Ribi Forclaz A. 2011. A New Target for International Social Reform. The International Labour Organization and Working and Living Conditions in Agriculture in the Inter-War Years, „Contemporary European History”, nr 20, s. 307-329,

/// Speich Chassé D. 2011. The Use of Global Abstractions. National Income Accounting in the Period of Imperial Decline, ,Journal of Global History”, t. 6, s. 7-28.

/// Speich Chassé D. 2013. Die Erfindung des Bruttosozialprodukts. Globale Ungleichheit in der Wissenschaft in der Wissensgeschichte der Ökonomie, Vandenhoeck \& Ruprecht.

/// Szturm de Sztrem E. 1939. Przedmowa, „Mały Rocznik Statystyczny”, R. 10, s. V-VI.

/// Toporowski J. 2013, Michat Kalecki: an Intellectual Biography, t. 1: Rendezvous in Cambridge 1899-1939, Palgrave Macmillan.

/// Warriner D. 1953. Some Controversial Issues in the History of Agrarian Europe, „The Slavonic and East European Review”, t. 32, nr 78, s. 168-186.

/// „Mały Rocznik Statystyczny”. 1930-1939, R. 1-10.

\section{/// Abstrakt}

Artykuł traktuje o kluczowej postaci polskiej międzywojennej statystyki i ekonomii - Ludwiku Landau (1902-1944) - i jego roli w definiowaniu Europy Wschodniej jako jednego z obszarów gospodarki światowej 
w pierwszej połowie XX wieku. Główna praca statystyczna tego badacza pt. Gospodarka światowa (1939), analizująca m.in. newralgiczne i pośrednie miejsce Polski na gospodarczej mapie ówczesnego kapitalizmu, stanowiła jedna z pierwszych prób stworzenia opisu tego, co dziś nazywamy globalnymi nierównościami. Ten sposób wyobraźni społeczno-ekonomicznej, pionierski w latach 30., stał się oczywistym elementem oglądu świata po II wojnie światowej, a zwłaszcza w okresie dekolonizacji. Artykuł śledzi intelektualne korzenie dzieła Landaua, które sięgają XIX wieku: środkowo- $i$ wschodnioeuropejski marksizm oraz międzynarodową statystykę porównawczą lat 20. i 30. XX wieku.

Słowa kluczowe:

Ludwik Landau, Róża Luksemburg, marksizm, historia statystyki, globalne nierówności

\section{/// Abstract}

This article deals with a key figure of interwar Polish statistics and economics, Ludwik Landau (1902-1944) and his contributions to understanding Eastern Europe as part of one world economy in the first half of the twentieth century. His key statistical publication, entitled World Economy (1939), was one of the first attempts to depict the world through the lens of global inequalities, a socio-scientific imaginary that became salient and taken for granted after the Second World War and in the wake of decolonization. The article aims to explain the ways in which Central and East European Marxism, on the one hand, and international comparative statistics, on the other, were two intellectual resources that Landau combined in his representation of the vulnerable position of Eastern Europe in global capitalism.

Keywords:

Ludwik Landau, Rosa Luxemburg, Marxism, history of statistics, global inequalities 